\title{
Using Speech-act Theory as a Means of Analysing the Phenomenon and Essence of "Dirty Talks" in Sports
}

\author{
Lei $\mathrm{Xu}^{1}$ \\ ${ }^{1}$ School of Foreign Languages \& Literature, Yunnan Normal University, Kunming, P.R. China \\ Correspondence: Lei Xu, School of Foreign Languages \& Literature, Yunnan Normal University, Kunming, Yunnan, \\ P.R. China. Tel: 86-182-1383-6246. E-mail: 1061959820@qq.com
}

Received: January 8, 2015

Accepted: January 22, 2015

Online Published: January 24, 2015

doi:10.5430/elr.v4n1p14

URL: http://dx.doi.org/10.5430/elr.v4n1p14

\begin{abstract}
In this article, Speech-act Theory will be used as a means of analysing the essence of the prevalent phenomenon"dirty talks" in sports, especially in basketball and soccer games which the author is familiar with. Firstly, the author will give a literature review of Speech-act Theory which was first proposed by Austin and then was developed by Searle and other linguistic scholars. Then authentic examples of dirty talks in sports games will be given, and Speech-act Theory will be used as a way of analysing the locutionary, illocutionary, and perlocutionary forces of these trash words. Finally, based on the analysis of the listed dirty talks in the article, the author will draw a conclusion which emphasises the essence of dirty talks in sports games and give his suggestions about how to decrease and mitigate the negative impact of dirty talks in sports games and purify the atmosphere of sports by educating and raising athletes' awareness of civilization and right sense of value and judgment about dirty talks.
\end{abstract}

Keywords: Dirty talks, Trash words, Sports games, Speech-act theory

\section{Introduction}

Sports are regarded as a globe voice without geographic boundary or barrier between countries. No matter wherever you are from, whatever language you speak, whichever color your race is, everyone can communicate with each other, exercise body and enjoy fun by playing sports. As the Olympic Charter proclaims, "Faster, higher, and stronger", it is the real essence of sports and is always the ultimate goal of the sports games. However, with the proliferation of commercial advertisements and the striving for profitable money bring about by fierce sports games, the purity of the original sports games has been blemished. Sports are no longer only played for improving friendship, cross-cultural communication, mutual understanding or showing respect with each other. They are replete with dirty talks, conflicts, violence which showed by deliberate flagrant fouls that may cruelly end a player's career. Sports leagues such as NBA, NFL, La Liga BBVA (Spanish League), English Premier League are world-wide popular and attracts billions of sports fans to buy tickets to enter the gym or recline on the comfortable sofa and watch TV live broadcasting to enjoy the most exciting games in which the genius players' eye-catching skills and competitiveness just escalate the hot flow of your blood and relieve you of the daily onerous work or study when you are immerged in such leisurely free time. Worldwide hot popular games such as Spanish and English Derby in soccer (the most competitive and exciting games within the same country between two top teams), the games between Miami Heat and Los Angeles Lakers in NBA, etc. are definitely a feast to sports fans and it is the wonderful channel and golden opportunity for the countries which host the sports events to attract more and more tourists, foreign investments, and other invisible benefits to their people. As a consequence, the sports games are no longer just for competing for the ultimate championship and pursuing glory, they are also an open window to showing your distinctive advantages and welcoming the whole world to come.

\section{Literature Review: The Speech-act Theory}

Since the Speech-act Theory has been put forward by Austin, it has been widely used to analyse and explain the meanings, effects and consequences of the speech conveyed by interlocutors in novels, plays, dramas, sports and other real-life contexts.

A speech act in linguistics and the philosophy of language is an utterance that has performative function in language and communication. According to Kent Bach (1979), "almost any speech act is really the performance of several acts at once, distinguished by different aspects of the speaker's intention: there is the act of saying something, what one 
does in saying it, such as requesting or promising, and how one is trying to affect one's audience." The contemporary use of the term goes back to J. L. Austin's development of performative utterances and his theory of locutionary, illocutionary, and perlocutionary acts. Speech acts are commonly taken to include such acts as promising, ordering, greeting, warning, inviting and congratulating.

According to Austin (1962), Speech acts can be analysed on three levels:

1. A locutionary act, the performance of an utterance: the actual utterance and its ostensible meaning, comprising phonetic, phatic and rhetic acts corresponding to the verbal, syntactic and semantic aspects of any meaningful utterance;

2. An illocutionary act: the pragmatic 'illocutionary force' of the utterance, thus its intended significance as a socially valid verbal action;

3. And in certain cases a further perlocutionary act: its actual effect, such as persuading, convincing, scaring, enlightening, inspiring, or otherwise getting someone to do or realize something, whether intended or not.

To give a simple and conclusive definition, Speech-act theory has 3 integrate parts:

1. Locutionary act: the utterance of a sentence.

2. Illocutionary act: the very act of the sentence.

3. Perlocutionary act: the effects or consequences of the sentence.

Illocutionary act is a term in linguistics introduced by the philosopher John L. Austin in his investigation of the various aspects of speech acts. We may sum up Austin's terminology with the following example. In uttering the locution "Is there any salt?" at the dinner table, one may thereby perform the illocutionary act of requesting salt, as well as the distinct locutionary act of uttering the interrogatory sentence about the presence of salt, and the further perlocutionary act of causing somebody to hand one the salt.

The notion of an illocutionary act is closely connected with Austin's doctrine of the so-called 'performative' and 'constative utterances': an utterance is "performative" if, and only if it is issued in the course of the "doing of an action" (Austin, 1955), by which, again, Austin means the performance of an illocutionary act (Austin, 1955). According to Austin's (1962) original exposition in How to Do Things With Words, an illocutionary act is an act (1) for the performance of which I must make it clear to some other person that the act is performed (Austin speaks of the 'securing of uptake'), and (2) the performance of which involves the production of what Austin calls 'conventional consequences' as, e.g., rights, commitments, or obligations (Austin, 1955) Thus, for example, in order to make a promise I must make clear to my audience that the act I am performing is the making of a promise, and in the performance of the act I will be undertaking an obligation to do the promised thing: so promising is an illocutionary act in the present sense. Since Austin's death, the term has been defined differently by various authors.

In Austin's (1955) point of view, the illocutionary act is the focus and most important part of the Speech-act theory, because the illocutionary force accounts for more than what the words mean. Many define the term "illocutionary act" with reference to examples, saying for example that any speech act (like stating, asking, commanding, promising, and so on) is an illocutionary act. This approach has generally failed to give any useful hints about what traits and elements make up an illocutionary act; that is, what defines such an act. It is also often emphasised that Austin introduced the illocutionary act by means of a contrast with other kinds of acts or aspects of acting: the illocutionary act, he says, is an act performed in saying something, as contrasted with a locutionary act, the act of saying something, i.e. the very utterance of a sentence; and also contrasted with a perlocutionary act, an act performed by saying something, i.e. the effects or consequences of the sentence.

According to the conception adopted by Bach and Harnish in 'Linguistic Communication and Speech Acts' (1979), an illocutionary act is an attempt to communicate, which they analyse as the expression of an attitude. Another conception of the illocutionary act goes back to Schiffer's book 'Meaning' (1972, p. 103), in which the illocutionary act is represented as just the act of meaning something.

According to a widespread opinion, an adequate and useful account of "illocutionary acts" has been provided by John Searle $(1969,1955,1979$.). In recent years, however, it has been doubted whether Searle's account is well-founded. A wide ranging critique is in FC Doerge (2006). Collections of articles examining Searle's account are: Burkhardt (1990) and Lepore / van Gulick (1991).

Several speech act theorists, including Austin himself, make use of the notion of an illocutionary force. In Austin's original account, the notion remains rather unclear. Some followers of Austin, such as David Holdcroft, view 
illocutionary force as the property of an utterance to be made with the intention to perform a certain illocutionary act - rather than as the successful performance of the act (which is supposed to further require the appropriateness of certain circumstances). According to this conception, the utterance of "I bet you five pounds that it will rain" may well have an illocutionary force even if the addressee doesn't hear it. However, Bach and Harnish assume illocutionary force if, and only if this or that illocutionary act is actually (successfully) performed. According to this conception, the addressee must have heard and understood that the speaker intends to make a bet with them in order for the utterance to have 'illocutionary force'.

If we adopt the notion of illocutionary force as an aspect of meaning, then it appears that the intended 'force' of certain sentences, or utterances, is not quite obvious. If someone says, "It sure is cold in here", there are several different illocutionary acts that might be aimed at by the utterance. The utterer might intend to describe the room, in which case the illocutionary force would be that of 'describing'. But she might also intend to criticise someone who should have kept the room warm. Or it might be meant as a request to someone to close the window. These forces may be interrelated: it may be by way of stating that the temperature is too cold that one criticises someone else. Such a performance of an illocutionary act by means of the performance of another is referred to as an indirect speech act.

Austin (1955) highlighted a conceptual gap in the understanding of speech. Not only do we utter words, what he calls 'locutions', but we also act with our speech. These acts he categorizes as perlocutionary and illocutionary. Of these two, the former is relatively easy to understand. We utter certain words in order that they bring about certain effects. If I shout 'me, here' or 'no defense' in a basketball game, then this will notice my teammates to pass me the ball; if a referee in a soccer game cries, "offside!", this utterance will cause the striker to stop running to shot the ball; if a coach in a sports game calls the off-court official to use a substitution player, the official will immediately raise a shining plate which informs the player on court who is called to be replaced and need to come back to rest on the bench; if a player on a football pitch suddenly cries out, " injury" or "help", it means he/she cannot play any longer, and the stretcher or ambulance car quickly shows to carry the injured player off court to get an immediate treatment; if a soccer player or manager shouts out complaints to a referee's judgment by using humiliating or insulting words, he/she will immediately get a red warning card and be sent to auditorium or directly to the locker room, deprived of ensuing participation in the ongoing game. So our speech can be described in terms of the simple sounds omitted (locutions), and as an act to bring about various consequences (perlocutions). However, and this is Austin's key insight, speech can be thought of as an act in-and-of itself. This is what he calls "illocution".

The easiest way to show what Austin means is also through a number of examples. If a referee dressed in black on a football pitch shows a player a yellow card, then he has warned the player who committed the violent tackles against the rival should watch out his behavior, otherwise, he will be stopped to play and be sent off to the bench if he commits another forbidden dangerous foul and get a red card as a consequence. If a hearer says, 'I beg your pardon', he just mean he didn't follow what the speaker said and thus asks the speaker to repeat the former unheard voice again. If a vicar says, 'I now pronounce you man and wife' in a church, then he announced the marriage of the couple. These are examples of acts - warning, requesting and marrying. Initially this distinction may seem superficial, yet on careful inspection there is a genuine difference. Consider another example from Saul:

Suppose George W Bush appears on TV and utters the words 'I hereby resign'. This act may have many perlocutionary effects. The perlocutionary acts might include making Democrats happy, making Republicans nervous, shocking the world, and selling lots of newspapers. There is just one illocutionary act, however, and this is the act simply of resigning the presidency of the United States. Like many other acts, not just anyone can perform it. (Saul 2003, p.86,)

There are a number of accounts of how best to understand illocution. However, for the sake of argument, I will not only assume that illocution makes sense, I will borrow Hornsby's (1994) useful characterization. Hornsby suggests that other accounts explaining illocution have been on the whole obscure, reliant on doubtful tests and over-dependent on the notion of convention. For instance, consider an account that tries to explain illocution in terms of consequences alone. This is problematic. Consequences seem to be as much a part of the picture when we consider illocutions as when we consider perlocutions. Consider, for example, 'warning', which is an illocution. For someone to successfully warn someone there will necessarily be certain consequence(s), such as that they are warned. So, according to Hornsby, to demarcate illocution, focusing on consequences is not sufficient.

There is then a danger of losing the distinction between illocution and perlocution altogether, and our project will fall at the first hurdle. However, Hornsby suggests a plausible way to proceed. We should not rely on linguistic tests, consequence or convention. The key to understanding illocution is reciprocity. If I warn someone - an illocutionary 
speech-act - then what does there need to be for this to take place? Well, it seems that what is required is simply certain receptiveness on the audience's part, i.e. that the audience takes me to have said what I meant. Reciprocity is the condition under which people can recognize one another's speech as it is meant to be taken. Such a background of reciprocity allows for Hornsby (1994, p. 194) to stipulate a working definition of illocution. Let us consider an example to illustrate this definition. Imagine we are trying to work out whether the mathematics teacher asserting that ' $2+2=4$ ' is an illocutionary act. According to Hornsby, it is if (and only if) the conditions are right. The conditions are right if they allow the class to take the teacher to be asserting ' $2+2=4$ '. If these conditions are not in place, then asserting ' $2+2=4$ ' in this context is not an illocutionary act.

The concept of an illocutionary act is central to the concept of a speech act. Although there are numerous opinions regarding how to define 'illocutionary acts', there are some kinds of acts which are widely accepted as illocutionary, for example warning, promising, ordering, requesting and refusing.

Following the usage of, for example, John R. Searle, "speech act" is often meant to refer just to the same thing as the term illocutionary act, which John L. Austin had originally introduced in How to Do Things with Words (published posthumously in 1962). Searle's (1969) work on speech acts is also commonly understood to refine Austin's conception. However, some philosophers have pointed out a significant difference between the two conceptions: whereas Austin emphasized the conventional interpretation of speech acts, Searle emphasized a psychological interpretation (based on beliefs, intentions, etc.).

According to Austin's preliminary informal description, the idea of an "illocutionary act" can be captured by emphasizing that "by saying something, we do something", as when someone issues an order to someone to go by saying "Go!", or when a minister joins two people in marriage saying, "I now pronounce you husband and wife."

An interesting type of illocutionary speech act is that performed in the utterance of what Austin calls performatives, typical instances of which are "I nominate John to be President", "I sentence you to ten years' imprisonment", or "I promise to pay you back." In these typical, rather explicit cases of performative sentences, the action that the sentence describes (nominating, sentencing, promising) is performed by the utterance of the sentence itself.

Searle (1975) has set up the following classification of illocutionary speech acts:

1. $\quad$ assertives $=$ speech acts that commit a speaker to the truth of the expressed proposition, (e.g. reciting a creed)

2. $\quad$ directives $=$ speech acts that are to cause the hearer to take a particular action, (e.g. requests, commands and advice)

3. $\quad$ commissives $=$ speech acts that commit a speaker to some future action, (e.g. promises and oaths)

4. $\quad$ expressives $=$ speech acts that express the speaker's attitudes and emotions towards the proposition, (e.g. congratulations, excuses and thanks)

5. declarations $=$ speech acts that change the reality in accord with the proposition of the declaration, (e.g. baptisms, pronouncing someone guilty or pronouncing someone husband and wife)

\section{Analysing the Phenomenon and Essence of "Dirty talks" in Sports Games}

In various sports games such as in NBA and English premier League, dirty talks between rivals are common and prevalent in the game, and sometimes are even indispensible ingredients which help to entertain and catch the eyes of the enthusiastic audience.

Dirty talks or trash words happen in nearly all of the games where frequent and fierce body contacts are inevitable. I conclude that dirty talks frequently happen because of the following root causes.

\section{Reason 1. The unharmonious growing family background}

The majority of sports players were born poor and were raised up in an unharmonious family environment destitute of parental care and inundated with bludgeons, family violence and physical abuse. Their parents were impatient to talk with them in a reasonable manner when they unintentionally made a mistake. Instead, their parents usually resorted to fist and stick to "educate" their children. As a result, a slap on the face and a hit on the buttocks are a common routine. As you can imagine, young kids brought up by such family would in a very likelihood imitate their parents' aggressive treatment to others and impute their resentful childhood experiences to their future on-court rivals by inhumane fouls and vulgar dirty talks to release their anger, temper, disappointment and complaint. 


\section{Reason 2. The lack of formal education and bad habit formed in school.}

Many of the sports players just received sporadic primary and secondary mandatory school education before they became professional players. In addition, they were usually the problematic students in school who didn't bother to learn useful and practical knowledge which would definitely offer them the norm of courtesy and polite behaviors and mould them into civilized people. Instead, they were usually involved into verbal and physical violence and got used to bullying other disadvantaged peers by virtue of their physical advantages.

\section{Reason 3. The negative community influence in their childhood}

Because most of the athletes were born in the impoverished social community filled with drugs and guns, pornography and prostitutes, prejudice and persecution, violence and bully such as the famous New York Brooklyn ghetto, where a lot of black children who were crazy about playing basketball later became rising stars in the NBA. You can imagine the most critical period in the growing of a child which was spent among gangsters, hooligans, and street battles and conflicts would have a lifelong negative impact on the kids when they later became professional athletes and then brought these rooted bad behaviors and propensity to aggressiveness formed throughout their childhood into the games by easily involved into fights and dirty talks against their opponents.

\section{Reason 4. Used as an effective strategy to interfere with rivals in the game}

Perhaps this is the most salient and visible reason we can detect from the former listed invisible profound reasons. When a player is standing behind the free-throw line in a basketball game, ready to shoot the ball, especially when it is in the clutch moment, you can always find a player from the opponent team comes forward to the free-thrower, whispers in his ears some trash words, such as "you are such a damn bad shooter" or "you can't make the motherfucking shoot" or "you will shoot an airball". Under such pressure, the inexperienced player usually loses composure and immediately talks back to the intruder as a counterattack, then misses the crucial free-throw shoots. In this case, the dirty talks take effects - they successfully distract the free-thrower and cause him to make a terrible mistake which may even determines the win or loss of the entire game. On another occasion, if a player is so hot at shooting and can't be stopped by the normal defense tactics, sometimes the coach of the opponent team will use "dirty talks" strategy to interfere with him. In this situation, a role player will be arranged to defend the target player. Not only will he foul hard at the player, with a technique foul, even at the price of a flagrant foul, but also he will talk dirty to the player, in order to enrage him to a further degree. This strategy is especially effective to young immature players who are impulsive and easy to be disturbed. If the strategy is successfully enforced, the "dirty talk" target will lose his mind, be infuriated, and step into the snare which is set for him by his opponent. If the player is greatly exasperated, he is very likely to be trapped in continuing exchanging dirty talks with his rival, can't focus his mind on the game and disqualified in his following performance. If the exasperation develops to an uncontrollable degree, the player may even stop playing the game and fight with the guy who keeps nagging at his ears in trash words with a forceful punch or kick. These forbidden impulsive behaviors will immediately cause his expelling from the court and cause great damage to his own team, in the meanwhile satisfies his rival team.

Take a famous classical example in soccer to illustrate. In 2006 World Cup final game-Italy vs. France, after Zidane, the mainstay and most crucial midfielder in the French team, scored the first goal in the seventh minute by a magical "spoon penalty" for France to lead before Materazzi - who had conceded the penalty - headed home an Andrea Pirlo corner 13 minutes later to level the scores. In the second half, Zidane organized nearly all of the threatening French attacks to Italy, and the balance of victory inclined to France apparently. However, a dramatic event happened and changed the result of the whole game. In the extra time of the game, the Italian defender Materazzi suddenly fell down hard, with both hands covering his face, looked very painful. The referee showed a red card to Zidane without hesitation, and the nearly unstoppable and greatest master player in the last decade had to leave the pitch with head deep down mixed with unimaginable unspeakable disappointment. This was the last game in his splendid carrier, but no one had ever predicted that he would fade away out of our vision and in front of his fans in such a disgraceful way-been deprived of the right to play till the last second and left the court without glory or applause. Time seemed frozen at that moment? What on earth happened a few seconds ago? All of the audience on TV missed the scene on live, however, the camera caught the whole process. The replay showed the world the missed dramatic scene-Zidane deliberately used his bald head to strongly butt Materazii out of great rage, and Materazzi took advantage of the opportunity to falling down hard, with the perfect act of unbearable suffering and pain. After Zidane was sent off court as a penalty to pay for his insane behavior, the momentum turned to Italy. With the advantage of players on court and the encouraging morale, Italy accomplished the historic marathon campaign by winning the final decisive penalty shootout. This time, Materazzi, the substitute player for injured starting line-up defender Nesta, became the hero and saved Italy. The final championship belonged to Italy, but what interested the audience most 
even long time after the game was what on earth caused Zidane, the experienced and sophisticated veteran to lose his mind and conducted such irrational behavior? The answer again boiled down to "dirty talks". The replay showed us that after a furious struggling for the ball, Materazzi advertently shouted to Zidane some trash words which lip-reading could easily tell. But what on earth had he said to Zidane? Some people wildly guessed that Materazzi said "you are a motherfucker bastard" or some other filthy trash words like that, but no one knew the exact answer which was not a secrete only between them. Because these words were so embarrassing, Zidane kept silence and refused to reveal the myth all the time.

After more than 1 year, under the pressure of the press and soccer fans of Zidane, Materazzi finally opened his mouth and set the record straight. He said that when they were struggling for the ball, they tore at jersey with each other. Zidane then ridiculed Materazzi that if Materazzi wants his jersey as a farewell gift, he can take it off and send it to Materazzi after the game right away. Taking this opportunity to enraging Zidane, Materazii answered back with quite vulgar, insulting dirty talks, "I don't want your jersey, I want your whore of sister." Using Speech-act Theory to analyse Zidane's and Materazzi's utterances, simply the soccer master's ironic words and the substitute defender's insulting reply are the "locutionary act"; the "illocutionary act" of Zidane's words is that he warned Materazzi to stop tangling with him and tearing at his jersey any longer; the "illocutionary act" of Marterazzi's reply is that in order to infuriate Zidane, he intentionally humiliated and slandered Zidane's sister that she was a prostitute who shamelessly sold her body and soul and disgracefully slept with whoremasters whoever could fuck her only if he pained the right price; and the "perlocutionary act" of their interlocution was that as Marterazzi had expected, Zidane lost his mind and butt Marterazii strongly with his head as a revenge, and Marterazii cleverly exaggerated the hit by pretending serious injury which directly caused Zidane to get a red card and was expelled from the football pitch and was directly sent off to the locker room.

In order to further illustrate "dirty talks" by using Speech-act Theory, I will take another typical "dirty talks" example in NBA. In 2012-2013 NBA regular season, when Boston Celtics was playing against New York Knicks, after a fierce body contact, Celtics' power forward Kevin Garnett purposefully whispered dirty talks in the ears of Knicks' small forward Camelo Anthony. Clearly, Camelo thought these trash words were not just a provocation as dirty talks usually intended, but completely crossed the line. As a consequence, Camelo was extremely furious and wrathful and thus lost his temper. No sooner had he heard these trash words than he pushed hard to Kevin with his mouth talking unstoppable dirty words back. At this time, Kevin, the canny and sophisticated veteran player just raised up his arms, kept his mouth closed, and stepped backwards to pretend that he was innocent in this conflict. Camelo followed Kevin all the way from the baseline to midcourt as they jawed at each other following the play, leading to technical fouls on both players by the referees' immediately stepping forward between them, pulling them apart in case of an ensuing fight which might become out of control in the end. After this interlude, Knicks led by Camelo lost the game to Celtics by virtue of Kevin' immoral but tactical provocation which totally made Camelo distracted in the remaining game, with at last had 20 points but shot 6 of 26 while battling his temper. Comparing with Camelo's averaging 34.4 points in his last 10 games and having a pair of 40-point performances last week, his performance in this game was completely disqualified and abnormal. This time, "Dirty talks" strategy again took a magical effect that disturbed the opponent player and helped the team win the game. Usually, "dirty talks" only happened on court and would have no aftermath after the game. But the funny thing was that even after the game, Camelo was still extremely furious about Kevin's talks, and couldn't let it go. He tried several times to breakthrough the body guards in order to enter the Knicks' locker room, trying to face Kevin and beat his ass off, but failed. His ensuing deeds were unprecedented and quite surprising to everyone. After failed to fight with Kevin in the locker room, he managed to stop the bus which Knicks' players were going to take back to the hotel, and succeeded to meet face to face with Kevin. If not the teammates and other court staff interfered in and mediated into the quarrel, and pulled them apart with all strength, a sharp altercation and confrontation was inevitable.

Fans and journalists were so confused and curious about what on earth Kevin had talked to Camelo in the game which caused such a turmoil. Camelo refused to disclose their conversation and just said he had tried to rushed into Knicks' locker room and stopped their bus for the sake of communicating with Kevin between two men and making clear what Kevin meant by saying those words in the game and where it came from. Obviously, Camelo felt so embarrassed and uncomfortable to talk about these dirty talks which hurt him so much, but under the pressure of the press and the league, Kevin finally opened his mouth and revealed the myth. What he said was, "Your wife tastes like Honey Nut Cheerios."

Now, let us analyse this speech again by using Speech-act Theory as a mirror. Needless to mention the "locutionary act" which is simply the words Kevin said, the Focus of this speech is its "illocutionary act" which implies that Kevin "tasted" Camelo's wife and felt it good. In another blunt language, Kevin meant that he had an extramarital 
affair with Camelo's wife and slept with her with great pleasure. Such explosive news to any sensible man in the world is unflinching because sexual partner's barefaced betrayal is the most shameful and least bearable thing in the world. Thus, extreme indignation and uncontrollable fury responded by Camelo is understandable now to everyone. The "perlocutionary act" of the speech is multi-faceted: both players got a technical foul as a warning; Camelo lost his mind and performed terribly bad in the remaining time of the game out of his being haunted by Kevin's dirty words, while Kevin laughed behind the scene and played so well to help his team finally win this tough game; after the game, Camelo calmlessly rushed to Knicks' locker room and then to stop the bus in order to have a duel with Kevin as everybody thought (in Camelo's words, he just wanted to talk peacefully with Kevin and set the record straight); because of Camelo's misconduct after the game by trying to make a trouble in interfering with Knicks players' leaving, the league penalised Camelo for 1 game suspension without fines, which could be the best result. On the contrary, Kevin escaped from more severe penalty by his acting as the weak side without making a quarrel after the game. Luckily, a few days later, the two sides conciliated with each other and pacified the rumors that Kevin didn't have an extramarital affair with Lala, Camelo's wife, by clarification via telephone. It's later stated that Kevin just said these dirty talks for a joke, not truly, in order to disturb and infuriate Camelo as the original purpose. Since everything has a limitation, so do dirty talks. Clearly, Kevin's trash words crossed the line. No one would blame the player for dirty talks even through they are not appreciated by civilized audience as long as they are expressed in a humorous, civilized, accepted way such as by using an irony like the example of Zinane listed above. However, we must defend the bottom line that these trash words should never go beyond to curse, slander, or even abuse opponents' loved ones, racial discrimination, sexual prejudice, religion disrespect and scorn, or any other form of radical personal attacks. In such extreme cases, unacceptable dirty talks are no longer regarded as a strategy to help to win the game, but are deemed as a violation and even a crime to the victim, which should be totally banned and be punished with severe game suspension and fines.

\section{Conclusions and Implications}

The author has elaborated the prevalent phenomenon of "dirty talks" and the covert essence of these trash words in sports games. By listing authentic examples in the sports games given in the article, it is proposed that we can utilise Speech-act Theory as a means of analysing the "hidden secrete" behind "dirty talks" of sports games. The utterance, the very act, the effects and consequences of "dirty talks", i.e. the so-called "locutionary act", "illocutionary act" and "perlocutionary act" in Speech-act Theory have great influence on sports game, not only on the game participants themselves, but also may determine the final victory or failure of the entire game and escalate to a more intense turmoil after the game. Because dirty talks have become an integrate and indispensible part of the competitive sports games and exert great negative impact on the athletes, the author suggests that it is imperative for sports coaches, managers and mass media to educate the players to raise awareness of sports civilization and courtesy. Or at least, team coaches and managers should stand against dirty talks and no longer use it as a humiliating and disgraceful strategy to help their team to win the game. In order to purify sports atmosphere, the author proposes that on the one hand, athletes must consciously avoid initiating dirty talks in the game and on the other hand, they must know how to correctly look at and respond to dirty talks. The wise player will regard it as a sheer uncivilized behavior out of rage, anger, disappointment or in some cases been used as a strategy by some immoral players to deliberately disturb and distract their rivals from the game and disorder their performances as a consequence. In this sense, this article is written for the athletes to understand better about the essence of dirty talks, in order for them to be more likely to ignore dirty talks and won't affect their performances when such nonsense is unexpectedly uttered by the rival. Therefore, if the player won't take dirty talks seriously, he/she will not be the poor victim. As long as the players understand the essence of "dirty talks" which have been elaborated in the article, it is believed that the victim player who suffered the dirty talks in the sports game will take it easy and let it go quickly without affecting their mood or the ensuing play. After knowing the root cause and covert secret of "dirty talks" in sports, we believe that the players can even give a disdainful laugh at it when their rivals speak out some "dirty talks", no matter inadvertently or intentionally. Let the trash talkers reap their own bitter fruits and ruin their own game by the complaints of their dirty talks, the victory always belongs to the one who practises harder and has more advantages than their rivals in sport itself rather than the one who can make more trash words.

\section{References}

Ambroise, B. (2010). From speech act theory to pragmatics: The loss of the illocutionary point. (= Pragmatics today). Retrived from https://halshs.archives-ouvertes.fr/halshs-00514810

Angela, G. (2014). Saying and doing: speech actions, speech acts and related events. European Journal of Philosophy, Vol.22, No.2, p. 173-199. http://dx.doi.org/10.1111/j.1468-0378.2011.00481.x 
Armin, B. (Ed.) (1990). Speech Acts, Meaning and Intentions: Critical Approaches to the Philosophy of John R. Searle.

Austin, J. L. (1955). How to do things with words: The William James lectures, J.O. Urmson (Ed.). Oxford: Clarendon Press.

Bach \& Harnish (1979). Linguistic communication and speech acts. Cambridge University Press.

Begley, I. (2013, January 8th). Opening Tip: Should Knicks star 'Melo'out? Espn. Retrieved from http://espn.go.com/blog/new-york/knicks/post/_id/33007/opening-tip-should-knicks-star-melo-out

Davidson, D. (2001). Inquiries into truth and interpretation. Oxford: Oxford University Press. http://dx.doi.org/10.1093/0199246297.001.0001

Doerge, F. C. (2006). Illocutionary Acts - Austin's Account and What Searle Made Out of It. Tuebingen University.

Hornsby, J. (1994). Illocution and its significance. In Foundations of speech act theory: Philosophical and linguistic perspectives, ed. S.L. Tsohatzidis. London: Routledge.

Langton, R. (1993). Speech acts and unspeakable acts. Philosophy and Public Affairs 22, no. 4: p. 293-330.

Ernest, L. \& Robert, V. G. (1991). John Searle and his Critics. Oxford: Basil Blackwell.

Sbisa \& Marina (2007). How to read Austin. Pragmatics, p. 461-473.

Searle, J. R. (1969). Speech Acts. Cambridge University Press. http://dx.doi.org/10.1017/CBO9781139173438

Searle, J. R. (1975). A Taxonomy of Illocutionary Acts, in: Günderson, K. (Ed.), Language, Mind, and Knowledge, Minneapolis, vol. 7.

Searle, J. R. (1979). Expression and meaning. Cambridge University Press. http://dx.doi.org/10.1017/CBO9780511609213

Searle, J. R. \& Vanderveken, D. (1985). Foundations of illocutionary logic. Cambridge University Press.

Carmelo Anthony Suspended for Post-Game Clash with Kevin Garnett. (2013, January 9th). Tmz. Retrieved from http://www.tmz.com/2013/01/09/carmelo-anthony-suspended-kevin-garnett-fight/

Carmelo Anthony pursues Kevin Garnett after loss (2013, January 8th). The Associated Press. Retrieved from http://www.usatoday.com/story/sports/nba/2013/01/07/boston-celtics-new-york-knicks-carmelo-anthony/181643 $1 /$

Howard Koplowitz. (2013, January $8^{\text {th }}$ ). KG Melo Fight: Did Kevin Garnett Tell Carmelo Anthony His Wife LaLa Vasquez 'Tastes Like Honey Nut Cheerios?' Ibtimes. Retrieved from http://www.ibtimes.com/kg-melo-fight-did-kevin-garnett-tell-carmelo-anthony-his-wife-lala-vasquez-tastes-hon ey-nut-cheerios

KG Allegedly Told Melo His Wife 'Tastes Like Honey Nut Cheerios'. (2013, January 9th). Newsone. Retrived from http://newsone.com/2128880/carmelo-anthony-kevin-garnett-honey-nut-cheerios-la-la-anthony/

Materazzi: Zidane was "super arrogant" (2006, July 12th). Chinaview. Retrived from http://news.xinhuanet.com/english/2006-07/12/content_4819795.htm

Materazzi wins British libel damages over Sun's claims about Zidane head-butt (2009 February 6th). Theguardian. Retrieved from http://www.theguardian.com/football/2009/feb/06/marco-materazzi-zinedine-zidane-the-sun-libel

Watt, S. (2006. July 10th). Italy wins World Cup in penalty shoot-out. ABC. Retrieved from $\mathrm{http}: / /$ www.abc.net.au/sport/content/200607/s1682264.htm

Whitwell, L. (2006, July 13th). Hall of Fame... Zinedine Zidane: He was God, the King, the Master, a man for the big occasion - however, there'll always be a butt. Dailymail. Retrieved from http://www.dailymail.co.uk/sport/football/article-2579891/Hall-Fame-Zinedine-Zidane-He-God-King-Master-m an-big-occasion-therell-butt.html 